\title{
Visionary of the principal leadership in improving the quality of learning
}

\author{
Murti Atika ${ }^{1}$, Edi Harapan ${ }^{2}$, Rohana Rohana ${ }^{3}$ \\ ${ }^{1}$ Sekolah Menengah Atas Negeri 1 Babat Supat, Indonesia \\ ${ }^{2}$ Universitas PGRI Palembang, Indonesia
}

\section{Article Info}

\section{Article history:}

Received Jul $15^{\text {th }}, 2021$

Revised Aug $19^{\text {th }}, 2021$

Accepted Aug 30 $0^{\text {th }}, 2021$

\section{Keyword:}

Principal

Quality Learning

\begin{abstract}
Through education, it is hoped that future generations will have the skills, talents, and attitudes of quality that can respond to competition in the age of globalization. In order to increase the quality of learning, the innovative leadership of school principals has a significant role to play. The goal of this study was to explain the principal's vision of improving the standard of learning and the barriers to visionary leadership at SMA Negeri 1 BabatSupat. In this research, through questionnaire, evaluation and observation, using qualitative approaches and data collection techniques. Data analysis used data reduction, data presentation and vehicle analysis in this research Conclusion or verification. The authenticity of creditable, transferable, defensible and verifiable data the findings showed that : (1) The principal's vision of enhancing the standard of learning at SMA Negeri 1 BabatSupat is to realize: "The realization of Indonesian people with character, achievement, competitive and friendly insight" (2) Students succeed in academic and nonacademic fields through the vision introduced by the principal. (3) The quality of learning through the leadership vision of the principal has guided school staff, especially educators, in the preparation of lesson plans according to the 2013 curriculum and the implementation of learning as a learning resource using current learning media in schools.(4) The challenges faced by the innovative leadership of the principal in enhancing the quality of learning in terms of the quality of teachers in learning are as follows: (1) lack of facilities for learning services that teachers can use in schools; (2) there are still some teachers who do not have teacher certificates, i.e. as many as 6 PNS teachers out of 17 current PNS teachers.
\end{abstract}

(C) 2021 The Authors. Published by IICET.

This is an open access article under the CC BY-NC-SA license (https://creativecommons.org/licenses/by-nc-sa/4.0

\section{Corresponding Author:}

Atika, M.,

Sekolah Menengah Atas Negeri 1 Babat Supat, Indonesia

Email: murtiatika71@gmail.com

\section{Introduction}

Training is an important part of the process of training qualified, capable, and professional human capital that can not be isolated from the process. A need to increase the quality of human capital is quality education. Training is often seen as the most strategic way of ensuring better conditions for social and economic growth.As a quality assurance agency, schools must see all facets of the components of the school. So that all aspects of the school are accountable for their respective roles and functions. 
Leaders are the subject that most individuals expect to promote the advancement of educational institutions, especially subordinates and, or society. Any time there is a shift in leadership in an educational institution, there are always great expectations that it will bring improvement in the participation of a new leader to the Institution of Education. This dream does not always come true, however. The involvement of new leaders is often insufficient to sustain the efficiency of educational institutions, and even the performance of educational institutions decreases.

The principal is a school leader who has the ability to make innovations, breakthroughs, and fresh breakthroughs in recognizing the success of the school he leads. To make improvements, the principal is mandated. The political influence that neither teachers nor workers have is sometimes referred to as this mandate. School development is supposed to be realized through the innovative leadership of the principal. Visionary leadership is a leader who has a strong future direction and shape, according to [1], which is an image of an accepted future with a high sense of togetherness and determination to making it happen. Meanwhile, visionary leadership, according to [2], is the capacity of a leader to develop, formulate, communicate,Socialize, transform, incorporate his ideal thoughts and the outcomes of social interaction between members of the organization and stakeholders as potential organizational ideals that need to be realized. Via any personal item. These two views include the understanding that innovative leadership must promote the reinforcement of concepts, observations, behavior and future orientation.

Visionary leadership is a profile of leadership that is seen as capable of performing adaptive organizational success, often predicting potential changes. In its results, visionary leadership will be focused on the deepening and sense of the institutional vision derived from the institution's internal conditions and external conditions in various dimensions,Political, economic, social, political, cultural and demographic inclusiveness.

\section{Method}

Where this work was performed at the academic year SMA Negeri 1 Babat Supat, Musi Banyuasin Regency, 2020/2021. The research period was carried out over a period of 3 (three) months, from September 2020 to November 2020.This analysis uses qualitative explanations. The descriptive method is a method used to analyze the status of a community of people, an entity, a collection of c's, according to [3] The descriptive method is a method used in the present to analyze the status of a group of persons, an entity, a collection of circumstances, a thinking pattern, or a class of events."In a study data is needed. In collecting data, techniques are needed, both techniques in providing data, and techniques in classifying the data that has been collected. "Data is required in a study. Techniques are required in the collection of data, both techniques in the provision of data, and techniques in the classification of the collected data.[4] also claimed that the method of data collection is "the method used to collect data, while the technique of data collection is the method used to carry out data collection."The form that was selected.

In short, it can be assumed that a method is a method, while a technique is a way to carry out a chosen method. This analysis is a field study, because it is only possible to obtain the desired data from the field, the research venue. In this study, data collection techniques include theinterview and observation.

\section{Results and Discussions}

\section{Description of Profile For School}

Based on the data from the research results, sma negeri 1 babat supat is located at $\mathrm{km} .86$ babat, jalan raya palembang-jambi. in 2006, sma negeri 1 babat supat was founded and run. sma negeri 1 babat supat was first called sma negeri 2 sungai lilin, along with the times and regional changes (sub-district extension decentralization), then sma negeri 2 sungai lilin was of sma negeri 2 sungai lilin on the basis of the decree of the regent of musi banyuasin no: 022 of 2011 concerning the change of the name of smp / sma / smk negeri to musi banyuasin regency, it was officially changed to sma negeri 1 babat supat. a number of educators with a total of 36 teaching staff, consisting of 17 pns teachers and 19 honorarium teachers, are supported by the learning process carried out at sma negeri 1 babat supat.

Harmonizing education in the vision of SMA Negeri 1 Babat Supat is: "The realization of Indonesian people with character, achievement, competitive and environmentally friendly" In addition, the mission of the school is: (1) To instill a religious mindset, good character and leadership; (2) To deliver quality teaching and learning activities assisted by student input, curriculum, educational staff Management of schools, facilities and amenities and the surrounding environment; (3) Creation of Adiwiyata school: (4) Preparing students to be prepared to pursue and to succeed in science, sports and artistic skills; (5) Creation of a clean, green, 
attractive, safe, comfortable and friendly environment; (6) Promoting literacy programs to foster a reading culture.

\section{Definition of Data from Study}

Based on the results of research on the visionary leadership of school principals in improving the quality of learning at SMA Negeri 1 BabatSupat, an illustration has been obtained that the visionary leadership applied to improving the quality of learning at SMA Negeri 1 BabatSupat refers to the decision of the R.I. Ministry of Education and Culture and to the 2013 curriculum The results of this study were obtained from observations and supported by interviews with the principal and teachers of SMA Negeri 1 Babat Supat and were supplemented by documentation data and described as follows in order to complement the research data.

\section{The principal's vision as a pioneer in enhancing the standard of learning at SMA Negeri 1 Babat Supat}

The Vision Of SMA Negeri1 BabatSupatIs "The Realization Of Indonesian People With Character, Achievements, Competitive And Environmentally Friendly."

\section{Realization of human personality}

1. In this case, SMA Negeri 1 BabatSupat has made efforts to mold the actions of students to improve confidence and piety and noble character.

A strong spirit of reality can shape a good character (akhlakulkarimah)) The school plays a very important role in the process of shaping the character of children / students, forming a strong spirit of confidence in the character of an individual. Some examples of SMA Negeri 1 BabatSupat's character education include prioritizing discipline, students are required to read the Holy Qur'an in turns before class hours and students are also required to read

2. Increase the ability, intelligence, and interests of students according to their level of development and skills. In this situation, increasing the social care of students focuses more on social characteristics such as caring for the needy, natural disasters, and caring for fellow colleagues impacted by the disaster.

3. The diversity of the region and the environment's ability and characteristics. In order to clean up the school environment, students are often guided to work together.

4. The development of the SMA Negeri 1 Babat Supat curriculum takes account of the balance of the requirements for regional and national development as shown by the presence of Mulok PLH, which is a prerequisite and a function of Musii Banyuasin regency But not to neglect the national and global needs that are marked by the more realistic production of ICT.

5. The needs of the labour world;

6. Scientific, technical and artistic development;

7. The SMA Negeri 1 BabatSupat curriculum is designed to increase the tolerance and unity of religious groups and to pay attention in the school setting to the existing religious values in accordance with the expected core competencies.

8. Global development dynamics, where SMA Negeri 1 Babat Supat's curriculum is built so that students can compete internationally and coexist with other nations by equipping students with attitudes, knowledge and skills according to their interests so that they can develop them independently in real world / daily life;

9. Implementation of scientific-approached learning practices and authentic evaluation, covering the areas of attitudes, information and skills;

10. Development of extracurricular activities capable of improving the ability of students, as well as the development of scouting activities as compulsory extracurricular activities to be pursued.

11. The SMA Negeri 1 Babat Supat curriculum is developed by taking account of the local community's socio-cultural characteristics and by encouraging the preservation of cultural diversity.

12. The SMA Negeri 1 Babat Supat curriculum is designed in accordance with the educational unit's vision, mission, priorities, conditions and characteristics;

13. The SMA Negeri 1 Babat Supat curriculum is formed by incorporating national character values into documents and applying them both in the sense of classroom learning and in school life or in 
the world outside of school. This is confirmed by the results of interviews with the principal who stated: "By arranging each employee's assignment of employees, responsibilities and roles in accordance with the discipline they have.

Of course, planning to decide the employees, responsibilities and roles of each employee must be tailored to the discipline it owns in this case.

\section{Achieving Human Success}

Of course, the realization of an excellent school can not be distinguished from the success and integrity of a principal of the school, the level of student achievement in the academic and non-academic field.

\section{Generating A Competitive Human Being}

Competitiveness is the motivation of individuals to be superior to others and their skills in the past, so that they can appear on the scene of globalization. Includes competitive personalities:higher personality, elevated morale, independent, don't ever give up, network builders and builders, friendly with transfer, creative, efficient, knowledge of quality, global-focused, lifetime students

\section{Creating An Eco-Friendly View}

For all school members, to cultivate a habit of clean living habits and to love the environment, to maintain environmental functions by integrated learning. Realizing waste and environmental harm reduction in extracurricular sports. Conducting environmental behaviorlifetime students.

\section{The standard of learning at SMA Negeri 1 BabatSupat through the vision of the principal's leadership}

Based on research results, the quality of teaching at SMA Negeri 1 Babat Supat has improved over the last 9 years (2011) and now in 2020, with only 6 teachers out of 17 teachers with teacher certificates in 2011. There are civil servants $(35.29 \%)$ and 11 PNS teachers currently have certificates of education (64.71 percent ). It ensures that there are still 6 more teachers who do not have Certificates for educators.

Quality of learning at SMA Negeri 1 Babat Supat The quality of learning at SMA Negeri 1 Babat Supat has improved in terms of infrastructure over the last nine years up to 2020, with infrastructure facilities including additional focus facilities, additional computer units and additional laboratory space to complement the needs for enhancing the quality of learning. This is backed by the findings of interviews

"In addition, the results of the interview with the principal explained: "We tried to find teachers who do not have teacher certificates. This has been achieved since 2011, when the number of PNS teachers was 17 individuals and 11 individuals currently have teacher certificates."

\section{The visionary leadership of the principal in enhancing the standard of learning.}

Visionary leadership itself can be defined as a leader's ability to produce, formulate, communicate, socialize, transform, and execute ideal ideas that come from him or as a result of social interaction between members of the organization and stakeholders who are thought to be ideals. -the potential corporate priorities that need to be accomplished through the dedication of all components.Usually, a visionary leader tends to think creatively for the future of the organization he leads (area). This is in accordance with the view that leadership is an effort to raise the vision of the group to a higher level.

Based on the research data obtained, the visionary leadership of the principal in improving the quality of learning at SMA Negeri 1 Babat Supat has tried its best to realize the school's vision, mission and objectives, where the visionary leadership carried out by the principal can be said to be able to educate students about good behavior, obedience in worship, high discipline, and competitiveness.

In this case, the strategy of achievement in enhancing the standard of learning was decided by the principal of SMA Negeri 1 BabatSupat, where this was manifested in the vision and purpose of the school

\section{Limitations}

The challenges faced by the innovative leadership of the principal in enhancing the quality of learning are as follows, based on the research data collected. Unable to comply with the planned facilities where additional laboratory space, namely a language laboratory, is needed. There are only 10 Infocus units, 18 units should be, since there are 17 learning places at the moment, while 1 focus unit is used for multipurpose rooms. In each 
laboratory, there is still a shortage of functional tools available. The remedy that must be done in this case so that Organized cooperation between the central government and local governments will solve the problem of facilities and infrastructure. In order to increase educational performance, the facilities and infrastructure must then be strengthened with this cooperation, of course we must develop educational support facilities and infrastructure that include: 1. Physical facilities (school buildings, Laboratories, libraries, outdoor equipment, and athletic facilities such as basketball courts. -Tools for art, such as music and other equipment), 2. Nonphysical institutions. If the teaching system is of good quality, it can accelerate national growth through nonphysical means.

There are still teachers who do not have certificates of education. As for the principal's approach to enhance the standard of teaching in terms of the quality of students, training and seminars, MGMP, conferences, IHT and other educational seminars are included and conducted by the principal.In terms of the standard of teachers in learning, the following are: (1) absence of infrastructural learning tools That can be used in schools by teachers; (2) the teacher's handbook is normally more than one, but not a major guide for the content provided to be absorbed by students. (3)it is often difficult for students to deliver curriculum learning materials that have been plannedDigest, where the content of local content is less appealing to students;(4) there are still some teachers who do not have teacher certificates, including 6 PNS teachers out of 17 current PNS teachers; (5) student conduct in learning often not all students pay attention to the teacher's material; (6) students are passive in answering teacher questions and following a certain learning process, in addition to the overall learning process In pursuing learning, students are often noisy and critical; (7) instilling character in students (lack of discipline), where students often still arrive late, particularly every day before class begins during recitation activities.

\section{Documentation Overview Result Data}

In order to improve the study findings and supplement the research data, the results of the research data documentation are the results of teacher-related research (observation sheets), the results of interviews with the principal, the results of interviews with homeroom teachers at SMA Negeri 1 BabatSupat. Documentation of researchers' interviews, and other documentation.

\section{Conclusions}

It can be inferred as follows, based on the study outcomes. The vision carried out at SMA Negeri 1 Babat Supat by the principal as a leader in enhancing the standard of learning is to realize: "The realization of Indonesian individuals with character, achievement, competitiveness and an environmentally friendly environment."The principal's vision requires success. In the academic and non-academic fields gained by SMA Negeri 1 Babat Supat students, including the results of the students' national examination with the highest score of 4.49 in 2016/2017 and other students' non-academic achievements. The standard of SMA Negeri 1 Babat Supat learning through the vision of le principal's Leadership has driven school staff, especially educators, to compile lesson plans relating to the 2013 curriculum and to incorporate learning as a learning opportunity using learning media in schools. In addition, educators are expected to provide an evaluation of the learning results that have been provided so that they can be measured and given Follow-up on the achievement of the learning outcomes delivered

\section{References}

Arifin, Arviyan and Veithzal Rivai. 2019. Leaders and Leadership. Jakarta: Dian Pustaka. Triatna, C. and Aan K. 2016. Visionary Leadership Towards Effective Schools, Jakarta: Bumi Aksara. Prastowo, A. 2011 Qualitative Research: Learning Design Techniques. Jogjakarta: Diva Press. Sugiyono. 2015. Educational Research Methods, Quantitative Approaches, Qualitative and R \& D. Bandung: Alfabeta.

Djamarah, S.B. 2010. Research Methods and Statistics. Jakarta: Rajawali Press.

Arikunto, S. 2010. Research Procedure A Practice Approach. Revised Edition. Jakarta: Rineka Cipta. 
